\title{
Rose Bengal-photocatalyzed perfluorohexylation reactions of organic substrates in water. Applications to late-stage syntheses
}

\author{
Damian E. Yerien ${ }^{1} \cdot$ Sebastián Barata-Vallejo ${ }^{1,2} \cdot$ Daniela Mansilla $^{1} \cdot$ Al Postigo $^{1}[$ \\ Received: 14 October 2021 / Accepted: 1 December 2021 / Published online: 27 January 2022 \\ (c) The Author(s), under exclusive licence to European Photochemistry Association, European Society for Photobiology 2021
}

\begin{abstract}
The Rose Bengal-photocatalyzed perfluorohexylation of olefins, alkynes, and electron-rich aromatic compounds in water was achieved employing perfluorohexyl iodide as fluoroalkyl source and TMEDA as sacrificial donor under green LED irradiation. Alkenes and alkynes rendered products derived from the atom transfer radical addition (ATRA) pathway, and in the case of alkynes, exclusively as $E$-stereoisomers. These are the first examples of photocatalyzed ATRA reactions carried out excursively in water alone. The reactions of aromatic compounds under the current protocol in water present the advantage of employing a perfluoroalkyl iodide $\left(\mathrm{C}_{6} \mathrm{~F}_{13}-\mathrm{I}\right)$ as source of perfluorohexyl radicals. Examples of photocatalytic late-stage incorporations of fluoroalkyl moieties into two commercial drugs of widespread use are reported.
\end{abstract}

\section{Graphical abstract}

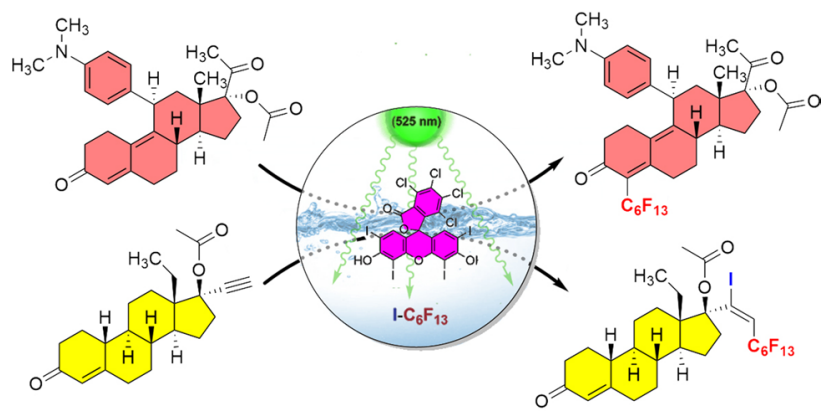

Keywords Photocatalyzed ATRA reactions · Photocatalysis in water · Photocatalytic perfluoroalkylation · Late-stage perfluoroalkylation · Perfluoroalkylation of arenes · Perfluoroalkylation of alkynes · Perfluoroalkylation of olefins

\section{Introduction}

Dedicated to Prof. Angelo Albini in the occasion of his 75th birthday.

Sebastián Barata-Vallejo

sebastian.barata@isof.cnr.it

Al Postigo

apostigo@ffyb.uba.ar

1 Departamento de Ciencias Químicas, Facultad de Farmacia y Bioquímica, Universidad de Buenos Aires, Junín 954, CP 1113, Buenos Aires, Argentina

2 ISOF, Consiglio Nazionale Delle Ricerche, Via P. Gobetti 101, 40129 Bologna, Italy
Organic transformations performed in water are undoubtedly advantageous when compared to traditional organic solventmediated reactions from several viewpoints ranging from the overall lower environmental impact, medium disposal in large-scale preparative transformations, and easy-to-handle and cost-saving operations. However, concerns in the use of water or aqueous media relate to the solubilization of organic substrates, additives, and catalysts and the possibility of forming water-derived reactive oxygen species in radical transformations [1]. 
On the other hand, visible light photocatalysis [2-6] has progressed as a powerful tool to enable organic synthetic transformations using organo(metallic) photocatalysts that affect electron transfer sequences promoting the formation of reactive radical or radical ion species which facilitate organic reactions and bypass the need for direct substrate irradiation.

The combination of water as reaction medium and visible light photocatalysis represents a promising alliance and a natural methodological advancement to achieve organic synthetic transformations. However, a vast majority of photocatalyzed reactions carried out in water promote the removal of contaminants, either organic or organometallic [7]. This is probably related to the above-mentioned production of reactive oxygen species from water, facilitated through the intervention of metals and semiconductors.

Notwithstanding, in the last ten years visible light-photocatalyzed organic transformations have been conducted in water or aqueous media, as recent review articles attest to the relevance of this association $[1,8]$.

In the realm of visible light photocatalysis, fluoroalkylation reactions play a considerable part, as generation of fluoroalkyl radicals $R_{F}$. by this method is well documented [7-9]. Our group has contributed to this subject with several examples [10-14] on visible light-photocatalyzed fluoroalkylation strategies in organic solvents.

One of the drawbacks associated with performing photocatalyzed reactions in pure water or buffer media is certainly a solubility issue, and the inadequacy of generating the $\mathrm{R}_{\mathrm{F}}$. species in these media [15]. For water-soluble organic substrates, authors have resorted to water-soluble photocatalysts [16] that enable the generation of fluoroalkyl radicals $\mathrm{R}_{\mathrm{F}}$. As a matter of fact, some of the aqueous- or water-photocatalyzed fluoroalkylation reactions informed are carried out in the reactants`organic interphase [17] or the fluorous phase.

However, a vast majority of photocatalyzed perfluoroalkylation transformations of organic substrates are carried out in $\mathrm{MeCN}$ or DMSO, or mixtures of these latter solvents with $\mathrm{MeOH}$ or acetone $[9,18]$. In particular, a few visible light photocatalyzed fluoroalkylation reactions of organic substrates in aqueous media have recently been reported [17, 19-26], and some are illustrated in Scheme 1. Although the use of aqueous organic mixtures significantly diminishes the environmental impact of the overall strategy, the ideal allwater medium where organic photocatalysts, substrates, and perfluoroalkyl group sources could perform the fluoroalkylation reactions of organic substrates remains fleeting.

Among the photocatalyzed fluoroalkylation strategies reported in aqueous media, the reactions of olefins [27] and alkynes employing polypyridyl complexes of Ir as photocatalysts [19, 21, 23, 24, 28], and the Umemoto reagent [21] (Scheme 1B) or perfluoroalkyl iodides [24, 28, 29] (Scheme 1A, C, D) as sources of fluoroalkyl radicals have been informed. On the other hand, for the photocatalyzed perfluoroalkylation of aromatic substrates, examples employing tetrabutylammonium decatungstate (TBADT) as photocatalyst in conjunction with the Langlois reagent (Scheme 1E) as $\mathrm{CF}_{3}$ radical source [25], or more recently the dyad vitamin B12 and Rose Bengal as photocatalysts in alliance with perfluoroalkyl bromides as fluoroalkyl radical sources [17], have been reported in aqueous media or water, respectively (Scheme 1F). However, photocatalyzed fluoroalkylation reactions in water alone have not been reported in atom transfer radical addition reactions [30] nor the employment of the readily available perfluoroalkyl iodides as perfluoroalkyl radical precursors in homolytic aromatic substitutions [17].

In this work, we present the visible light-photocatalyzed perfluorohexylation reactions of olefins, alkynes, and aromatic compounds employing perfluorohexyl iodide as source of perfluorohexyl radicals and Rose Bengal as organophotocatalyst in water alone as solvent.

\section{Results and discussion}

We firstly embarked on the investigation of the Rose Bengalphotocatalyzed perfluorohexylation reactions employing alkenes and alkynes as substrates in water.

The use of additives in photocatalyzed reactions either as base, sacrificial donors, or electron pools is crucial. In the latter roles, redox-active sacrificial donors are deemed necessary to regenerate (photo)catalysts or bring intermediates into redox neutrality. In a previous and seminal publication [14], we had successfully undertaken the Rose Bengal-photocatalyzed perfluoroalkylation reaction of activated arenes in $\mathrm{MeCN}$ as solvent, employing $\mathrm{Cs}_{2} \mathrm{CO}_{3}$ as base/additive. From then on, it became clear that $\mathrm{Cs}_{2} \mathrm{CO}_{3}$ functions as an excellent additive in numerous photocatalyzed reactions carried out in organic solvents $[10,11,13]$. We decided to employ $\mathrm{Cs}_{2} \mathrm{CO}_{3}$ as base/additive in our Rose Bengalphotocatalyzed perfluorohexylation reactions of alkenes and alkynes in water. We used allyloxy benzene as model substrate ( $0.2 \mathrm{mmol}), \mathrm{C}_{6} \mathrm{~F}_{13}$-I ( 3 equiv) as source of $\mathrm{C}_{6} \mathrm{~F}_{13}$ radicals, and Rose Bengal (RB, $5 \mathrm{~mol} \%$ ) as photocatalyst, in Ar-deoxygenated heterogeneous water mixture $(3 \mathrm{~mL})$, irradiating $(20 \mathrm{~h})$ with a high-power Green LED (3 Watts). However, no perfluoroalkylation product was found under these reaction conditions. When we replaced $\mathrm{Cs}_{2} \mathrm{CO}_{3}$ with $N, N, N^{\prime}, N^{\prime}$-tetramethylethylenediamine (TMEDA), 3 equiv, under the same reaction conditions, a $91 \%$ yield of product 1 was obtained (Table 1). Changing the quantities of $\mathrm{C}_{6} \mathrm{~F}_{13}$-I, TMEDA, and photocatalyst RB did not improve product 1 yield. We therefore applied our optimized reaction conditions consisting of substrate (alkene or alkyne, $0.2 \mathrm{mmol}$ ), 


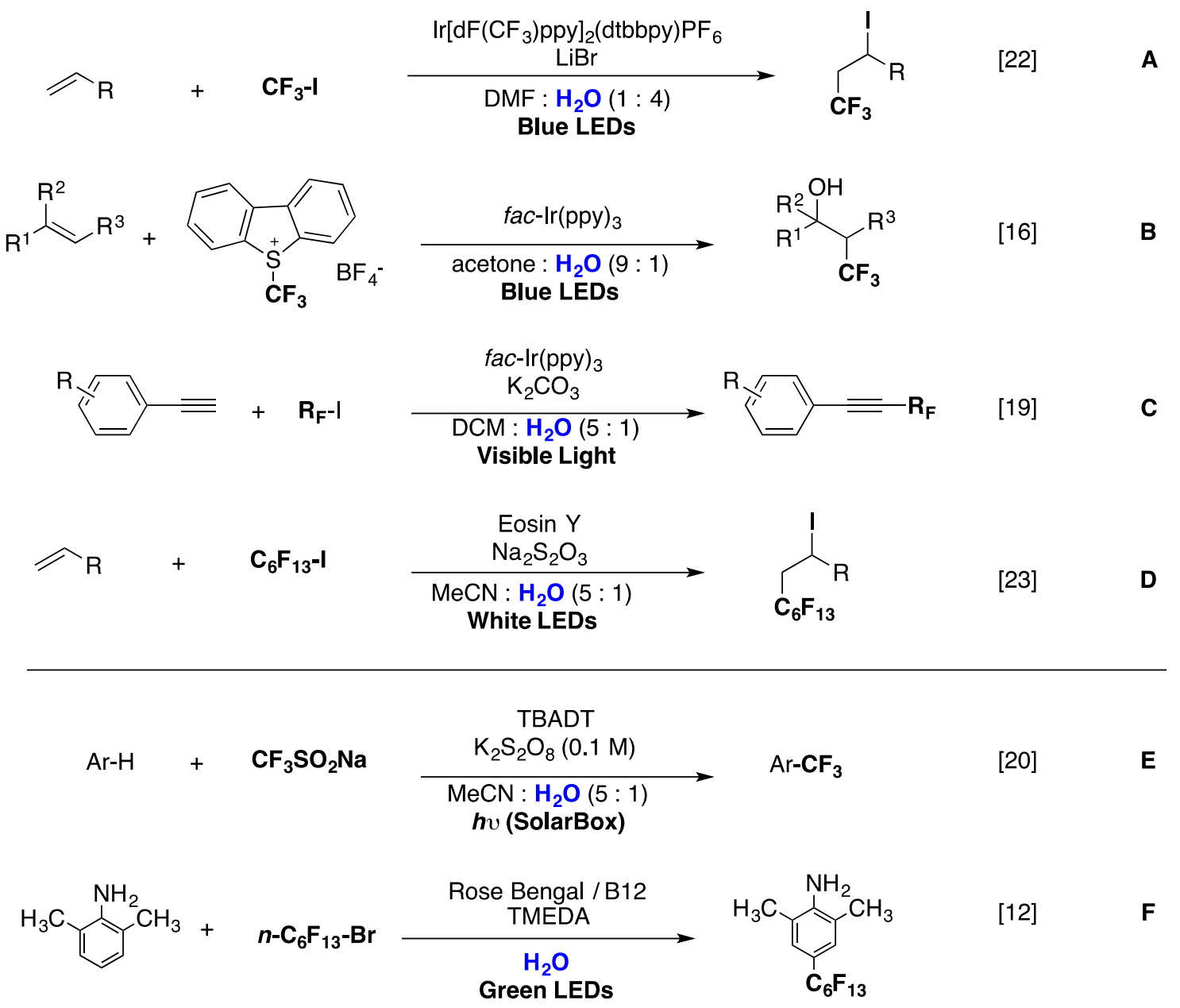

Scheme 1 Selected examples of the reported photocatalyzed fluoroalkylation reactions of organic substrates in water or aqueous media

$\mathrm{C}_{6} \mathrm{~F}_{13} \mathrm{I}$ ( 3 equiv), TMEDA ( 3 equiv), and $\mathrm{RB}$ as photocatalyst (5 mol\%), in Ar-deoxygenated water (3 mL).

Allyloxybenzene afforded $91 \%$ yield of product 1.

When we treated $( \pm)$-1-octen-3-ol under the standard reaction conditions, we obtained a mixture of the atom transfer radical addition products $\mathbf{2}$ and $\mathbf{3}$, in quantitative combined yield, in a 2.5:1 ratio (Table 1). Diastereomeric compounds $\mathbf{2}$ and $\mathbf{3}$ were successfully separated by silica gel column chromatography and characterized by one- and bidimensional NMR spectroscopy $\left({ }^{1} \mathrm{H},{ }^{13} \mathrm{C},{ }^{19} \mathrm{~F}\right)$. The preponderance of diastereoisomer $\mathbf{2}$ over $\mathbf{3}$ can be explained on the basis of the iodine atom being abstracted from the opposite face of the hydroxyl group of the $\mathrm{C}_{6} \mathrm{~F}_{13}$-substituted radical intermediate, see ESI, Scheme S1).

When phenylacetylene was used as substrate, product 4 was obtained in $78 \%$ isolated yield, exclusively in a $E$ configuration. Product $\mathbf{4}$ had previously been obtained [24] in $81 \%$ yield through the Ir-photocatalyzed reaction in DCM: $\mathrm{H}_{2} \mathrm{O}$, as a mixture of the $E: Z$ stereoisomers in a $86: 14$ isomeric ratio.
1-Heptyne reacted with $\mathrm{C}_{6} \mathrm{~F}_{13}$-I under the optimized photocatalytic conditions, affording $80 \%$ yield of product 5 [31], also as exclusive $E$-isomer. Product $\mathbf{5}$ had previously been synthesized by $\mathrm{Zn} / \mathrm{TiCl}_{4}$ one-electron reduction of $\mathrm{C}_{6} \mathrm{~F}_{13}-\mathrm{I}$ in DME as solvent, at $75^{\circ} \mathrm{C}$ in $70 \%$ yield as a mixture of stereoisomers [31].

To extend the utility of our methodology, we employed commercial alkyne drug $(D)-(-)$-Norgestrel acetate, the acetylated form of $(D)$-(-)-Norgestrel, a drug used as a hormonal medication and contraceptive [32]. We were gratified to observe a $50 \%$ isolated yield of $(D)-(-)$-norgestrel- $\mathrm{C}_{6} \mathrm{~F}_{13}$ derivative 7 (Table 1).

We then focused our attention to the Rose Bengal-photocatalyzed perfluorohexylation $\left(\mathrm{C}_{6} \mathrm{~F}_{13}\right.$-I, 3 equiv) reaction of activated arenes $(0.2 \mathrm{mmol})$ in Ar-deoxygenated water ( $3 \mathrm{~mL}$ ), employing TMEDA ( 3 equiv), under irradiation with high-power (3 W) green LEDs (Table 2).

When xylidine (2,6-dimethylaniline) was used as substrate, a $95 \%$ yield of product 8 [17] was obtained under the standard reaction conditions (Table 2). 4-Methylaniline 
<smiles>CC(=O)O[C@]1(C(C)=O)CC[C@H]2[C@@H]3CCC4=CC(=O)CCC4=C3[C@@H](c3ccc(N(C)C)cc3)C[C@]21C</smiles>

Ulipristal

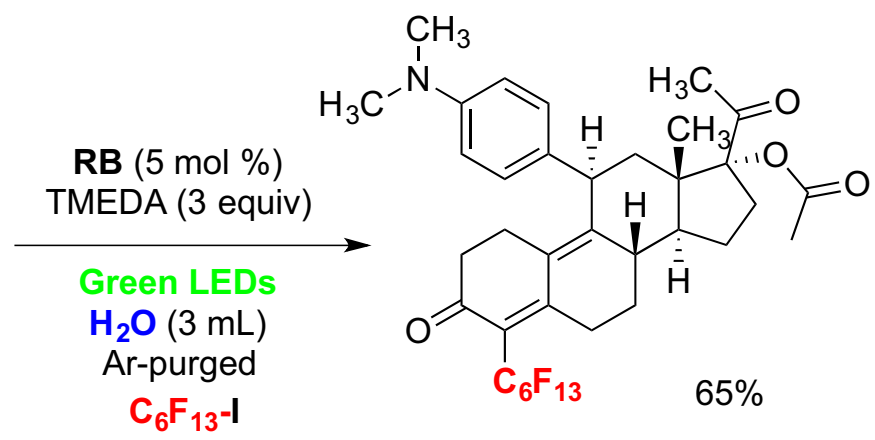

17 , Ulipristal- $\mathrm{C}_{6} \mathrm{~F}_{13}$

Scheme 2 Photocatalyzed perfluorohexylation reaction of Ulipristal in water

afforded $80 \%$ yield of 2-perfluorohexyl-4-methylaniline 9 (Table 2). 4-Methoxyaniline gave a mixture of 2-pefluorohexyl-4-methoxyaniline $\mathbf{1 0}$ and 3-perfluorohexyl4-methoxyaniline $\mathbf{1 1}$ in 50\% combined yield, in a ratio 10:11 $=20: 1$. When the same substrate was treated under Rose Bengal photocatalysis in $\mathrm{MeCN}$ as solvent [14], only a perfluoroalkylated product substituted at the 2-position was obtained. When 4-nitroaniline was employed as substrate, a $30 \%$ yield of 2-perfluorohexyl-4-nitroaniline $\mathbf{1 2}$ was formed. This result is very encouraging, since in the Rose Bengalphotocatalyzed methodology carried out in $\mathrm{MeCN}$ as solvent [14], this product 12 could not be formed at all, which is a telltale indication of the effect of water on the photocatalytic reaction.

Interested by the result of the methoxy-substituted arene (i.e., 4-methoxyaniline), where both products $\mathbf{1 0}$ and $\mathbf{1 1}$ are obtained, as opposed to the reaction carried out in $\mathrm{MeCN}$ as solvent [14], we undertook the perfluorohexylation of methoxy-substituted arenes under the Rose Bengalphotocatalyzed conditions in water.

When 4-tert-butylanisol is treated under the reaction conditions (Table 2), 50\% yield of product $\mathbf{1 3}$ is obtained. 1,2-Dimethoxybenzene yielded $55 \%$ of product 14 . 1,3,5-Trimethoxybenzene, instead, afforded $90 \%$ yield of 4-perfluorohexyl-1,3,5-trimethoxybenzene $\mathbf{1 5}$ in $90 \%$ yield.

It is interesting to confront the yields of products 8-15 obtained when an analogous methodology was carried out under the dyad photocatalytic system Rose Bengal/vitamin B12 employing perfluorohexyl bromide $\mathrm{C}_{6} \mathrm{~F}_{13}-\mathrm{Br}$ as source of $\mathrm{C}_{6} \mathrm{~F}_{13}$ radicals in water, as reported by some of us recently [17]. In this latter work [17], the use of $\mathrm{C}_{6} \mathrm{~F}_{13}-\mathrm{Br}$ as $\mathrm{C}_{6} \mathrm{~F}_{13}$ source was made possible by the co-catalyst vitamin $\mathrm{B} 12$. Although the yields obtained for products 8-15 are superior starting from $\mathrm{C}_{6} \mathrm{~F}_{13}-\mathrm{Br}$ than our current methodology employing $\mathrm{C}_{6} \mathrm{~F}_{13}$-I, the more readily availability of the latter can warrant a widespread use of the current methodology.
We treated a commercial drug Ulipristal acetate [33, 34], a medication used for birth control and uterine fibroids, which bears a phenyl-dimethylamino group under our standard photocatalytic conditions (Table 2). To our surprise, we obtained substitution of the enone moiety with the $\mathrm{C}_{6} \mathrm{~F}_{13}$ group in $65 \%$ yield, according to Scheme 2 , and no product derived from homolytic aromatic substitution was found.

Despite that both $(D)-(-)$-Norgestrel (Table 1) and Ulipristal (Scheme 2) possess enone moieties, the presence of the more reactive alkyne functionality in the former drives the reactivity toward the atom transfer radical addition reaction (ATRA) affording product 7 in 50\% yield. Comparatively, the highly conjugated enone system in Ulipristal (Scheme 2) is more reactive than the electron-rich aromatic moiety.

In order to uncover the reaction mechanism, a series of experiments were carried out, such as the reaction in the absence of photocatalyst, or light, where no perfluorohexylated product was encountered. The reaction in the presence of radical scavenger TEMPO ((2,2,6,6-Tetramethylpiperidin-1-yl)oxyl, 0.5 equiv) did not afford any perfluorohexylated product, but the TEMPO- $\mathrm{C}_{6} \mathrm{~F}_{13}$ adduct was observed instead, supporting the presence of ${ } \mathrm{C}_{6} \mathrm{~F}_{13}$ radicals in the system. A crucial step in these photocatalytic reactions is indeed the formation of $\mathrm{C}_{6} \mathrm{~F}_{13}$ radicals and two possible pathways, oxidative and reductive quenching cycles, can be proposed (Scheme 3) [35]. Upon excitation of the photocatalyst, $\mathrm{RB}^{*}$ could be oxidatively quenched by $\mathrm{C}_{6} \mathrm{~F}_{13}-\mathrm{I}$ affording ${ }^{\circ} \mathrm{C}_{6} \mathrm{~F}_{13}$ radicals, $\mathrm{I}^{-}$and $\mathrm{RB}^{{ }^{++}}$. Reduction of $\mathrm{RB}^{\cdot+}$ by electron donor TMEDA can regain RB into its active photoredox state, closing the photocatalytic cycle (oxidative quenching pathway, Scheme $3 \mathrm{~A}$ ). The other alternative would involve the initial reduction of RB* by TMEDA as an electron donor affording $\mathrm{RB}^{--}$, followed by a single electron transfer from $\mathrm{RB}^{--}$to $\mathrm{C}_{6} \mathrm{~F}_{13}$-I giving ${ }^{-} \mathrm{C}_{6} \mathrm{~F}_{13}$ radicals and Iand regenerating the photocatalyst $\mathrm{RB}$ (reductive quenching pathway, Scheme 3B). Indeed, for both quenching cycles 
(A) Oxidative quenching pathway

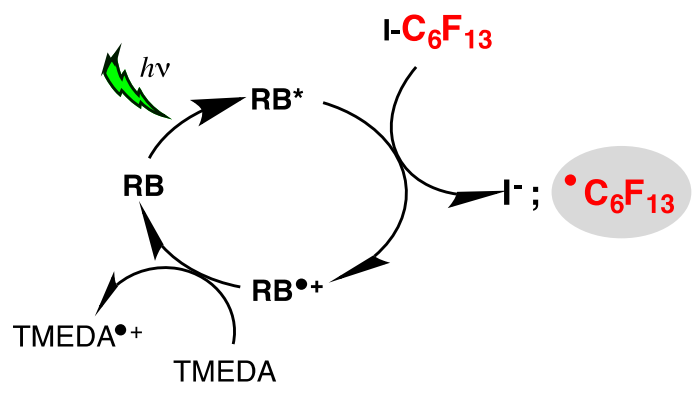

(B) Reductive quenching pathway

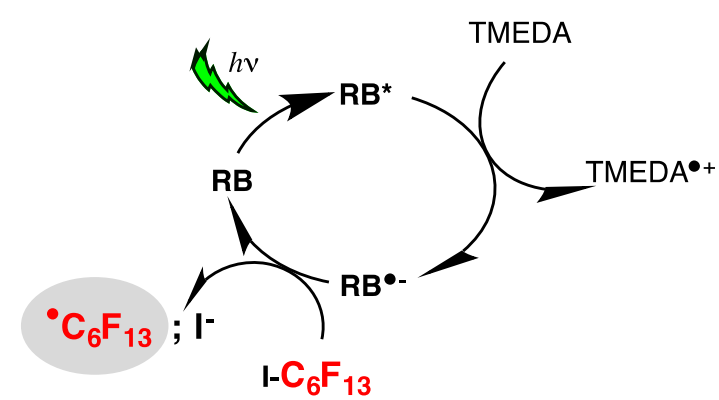

Scheme 3 Oxidative (A) and reductive (B) quenching cycles toward the formation of $\bullet \mathrm{C}_{6} \mathrm{~F}_{13}$ radicals

Table 1 Scope of the photocatalyzed (RB) perfluorohexylation reactions of olefins and alkynes $(0.2 \mathrm{mmol})$ in the presence of TMEDA ( 3 equiv) in Ar-purged water $(3 \mathrm{~mL})$ or otherwise noted, under green LEDs irradiation

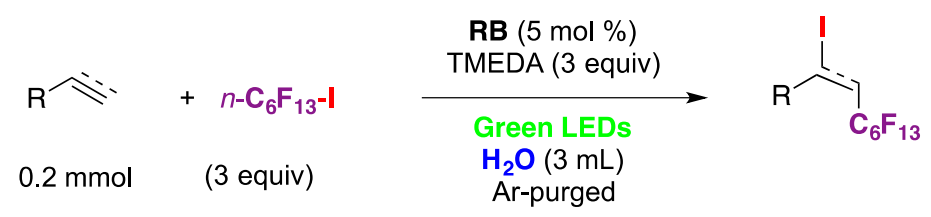

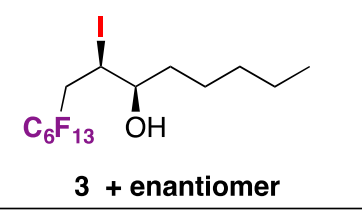

$1: 2=2.5: 1,99 \%$

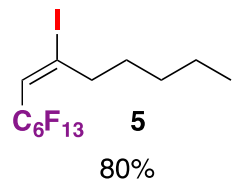

$50 \%$ (D)-(-)Norgestrel- $\mathrm{C}_{6} \mathrm{~F}_{13}$ a

Reaction time: $20 \mathrm{~h}$ under constant stirring at room temperature

Yields represent isolated yields

${ }^{\mathrm{a}} \mathrm{A}$ mixture of $\mathrm{MeCN}: \mathrm{H}_{2} \mathrm{O}, 1: 2$, was used

${ }^{\mathrm{b}}$ Reaction perform with 1 equiv. of $\mathrm{I}_{-} \mathrm{C}_{6} \mathrm{~F}_{13}$

the overall result is essentially the same, being the photocatalyst RB the species that facilitates the electron transfer process from the electron donor TMEDA to the ultimate electron acceptor $\mathrm{C}_{6} \mathrm{~F}_{13}-\mathrm{I}$ and generating $\bullet \mathrm{C}_{6} \mathrm{~F}_{13}$ radicals. In order to unequivocally distinguish from the two operating photocatalytic cycles, Stern-Volmer kinetic analyses were initially undertaken. Investigations started attempting the fluorescence quenching of RB upon addition of TMEDA in $\mathrm{H}_{2} \mathrm{O}: \mathrm{CH}_{3} \mathrm{CN}$ (1:1) as solvent but no suppression of fluorescence was observed, precluding the intervention of an electron transfer process from TMEDA to the RB* singlet excited state. This result is in agreement with the experiments reported by Hisaeda and coworkers [36], where the authors fail to quench the fluorescence of RB upon addition of triethanolamine. With these experimental data gathered, even though the reductive quenching pathway involving RB singlet excited state is excluded, the evaluation of the analogous quenching pathway involving RB triplet excited state would require additional laser flash photolysis measurements. Unfortunately, the poor solubility of $\mathrm{C}_{6} \mathrm{~F}_{13}$-I in the reaction media (or even in pure $\mathrm{CH}_{3} \mathrm{CN}$ ) does not allow the measurement of any reliable optical spectroscopy value from the Stern-Volmer kinetic analysis nor triplet quenching experiments could be performed. However, in a previous publication [14] we demonstrated the efficiency of the electron transfer process from the excited state of $\mathrm{RB}^{*}$ to 
Table 2 Scope of the photocatalyzed (RB) perfluorohexylation reactions of arenes $(0.2 \mathrm{mmol})$ in the presence of TMEDA ( 3 equiv) in Ar-purged water $(3 \mathrm{~mL})$ or otherwise noted, under green LEDs irradiation
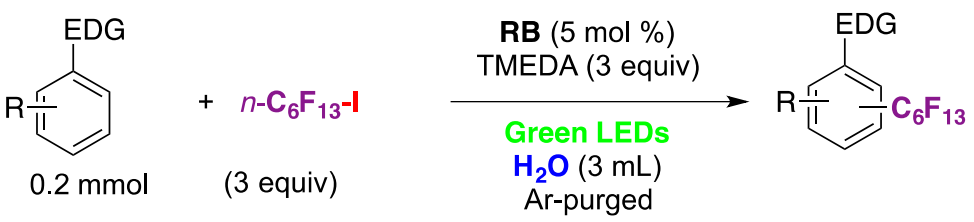<smiles>Cc1cc(C(F)(F)F)cc(C)c1N</smiles>

$8,95 \%$<smiles>Cc1ccc(N)c(C(F)(F)F)c1</smiles>

$9,80 \%$<smiles>COc1ccc(N)c(C(F)(F)F)c1</smiles><smiles>Nc1ccc([N+](=O)[O-])cc1C(F)(F)F</smiles>

$12,30 \%^{a}$
$10,11,50 \%$ a

$$
10=2-C_{6} F_{13} ; 11=3-C_{6} F_{13}
$$
$10: 11=20: 1$<smiles>COc1ccc(C(C)(C)C)cc1C(F)(F)F</smiles>

$13,50 \%$<smiles>COc1ccc(C(F)(F)F)cc1OC</smiles>

$14,55 \%$<smiles>COc1cc(OC)c(C(=O)O)c(OC)c1</smiles>

$15,90 \% \mathrm{a}$

Reaction time: $20 \mathrm{~h}$ under constant stirring at room temperature. Yields represent isolated yields

${ }^{\mathrm{a}} \mathrm{MeCN}: \mathrm{H}_{2} \mathrm{O}=1: 1$ used

$\mathrm{C}_{4} \mathrm{~F}_{9}$-I for a homogeneous system in $\mathrm{CH}_{3} \mathrm{CN}$. The difficulty of performing any optical measurements involving $\mathrm{RB}$ and $\mathrm{C}_{6} \mathrm{~F}_{13}$-I in heterogeneous water or aqueous media herein studied precludes us from obtaining any quenching constants that could be compared with those acquired involving a reductive quenching cycle of RB and TMEDA. For this reason and with the limited data available, the intervention of either a reductive or oxidative quenching pathways cannot be distinguished within the heterogeneous system studied. Further experiments to elucidate the actual quenching pathway of the photocatalyst are under way.

\section{Conclusions}

We herein present an environmentally friendly methodology to carry out perfluoroalkylation (perfluorohexylation) reactions of alkenes, alkynes, and aromatic compounds in water or aqueous media, employing Rose Bengal as photocatalyst and TMEDA as sacrificial donor. Throughout the photocatalytic process, a high stability of the photocatalyst Rose Bengal is observed in water or aqueous medium with $\mathrm{MeCN}$.

For the photocatalyzed reactions of alkenes and alkynes, products derived from the atom transfer radical addition
(ATRA) pathway are obtained, and in the case of alkynes, exclusively as $E$-stereoisomers. It is of note that the current protocol is the first report on a photocatalyzed ATRA reaction in water alone, since other informed photocatalyzed methodologies utilized mixtures of water with organic solvents $[24,28,29]$, thus rendering the current syntheses superior to other reported methodologies [24, 31].

Regarding the photocatalyzed perfluorohexylation reaction of electron-rich aromatic compounds, our methodology in water is an environmentally friendly alternative to other protocols reported [17] in water or aqueous media. As was also the case in analogous photocatalytic methodologies [17], we found that the reactions of aromatic nuclei with strong electron-withdrawing groups, such as $\mathrm{NO}_{2}$ groups, are made feasible when organic solvents [14] are replaced with water (current work). This brings to light the notorious effects of water in photocatalytic reactions, that go beyond polar or hydrogen-bonding interactions.

We also proved the feasibility of the late-stage introduction of a perfluoroalkyl moiety on two commercial drugs of considerable pharmacological relevance, such as the alkyne $(D)-(-)$-Norgestrel acetate and Ulipristal, where the $\mathrm{C}_{6} \mathrm{~F}_{13}$ group is attached to the alkyne function in the former, and the enone system in the latter. These 
results are quite encouraging from the synthetic point of view, since we proved the application of a late-stage perfluoroalkyl group incorporation in the last step of a synthetic protocol toward commercial pharmacophore.

The employment of the readily available perfluoroalkyl iodides renders our current investigation more accessible from the viewpoint of reagents, as compared to the employment of other fluoroalkylating reagents, such as Umemoto's, Langlois, Togni's, or perfluoroalkyl bromides reagents.

\section{Experimental}

\subsection{Materials and methods}

All reactions were carried out under argon atmosphere unless otherwise indicated. Water was purified with a Millipore system. Chromatography and extraction solvents, such as ethyl acetate, acetonitrile $(\mathrm{MeCN})$, dichloromethane (DCM), and $n$-hexane, were of chromatographic quality and used without further purification. 1-Iodotridecafluorohexane (perfluorohexyl iodide) was a commercial reagent and used without further purification. $N, N, N^{\prime}, N^{\prime}$-Tetramethylethylenediamine (TMEDA) was $99 \%$ pure and used as received from the supplier.

Dye Rose Bengal (4,5,6,7-tetrachloro-3',6'-dihydroxy$2^{\prime}, 4^{\prime}, 5^{\prime}, 7^{\prime}$-tetraiodo-3H-spiroisobenzofuran-1,9'-xanthen]3 -one) was $99.9 \%$ pure and used as received from the supplier. Organic substrates 2,6-dimethylaniline, 4-methylaniline, 4-nitroaniline, 4-methoxyaniline, 1,2-dimethoxybenzene, 1,3,5-trimethoxybenzene, and 4-tert-butylanisole were commercial and used as received. The biologically relevant substrates employed, Norgestrel and Ulipristal (both in the acetate form), were commercial and used without further purification. 2,2,6,6-Tetramethyl-1-piperidinyloxy (TEMPO) was an ultra-pure-grade reagent.

Analytical thin-layer chromatography (TLC) was performed on silica gel $60 \mathrm{~F} 254$ pre-coated plates $(0.25 \mathrm{~mm}$, Merck). TLC plates were visualized with ultraviolet light or by treatment with ceric ammonium molybdate (CAM) solution followed by heating. Purification of the reaction products was carried out by column chromatography using ultra-pure silica gel (230-400 mesh), standard silica gel for column chromatography (60 mesh), or silica gel for thin-layer preparative chromatography with fluorescent indicator (rhodamine).

The light sources were commercially available high-power LEDs ( $3 \mathrm{~W})$ : green light, LED of $\lambda_{\max }=525 \mathrm{~nm} \pm 2 \mathrm{~nm}, \mathrm{ET}=10 \mathrm{~mW}$.

\subsection{Photocatalyzed syntheses}

In a 4-mL glass reaction vial provided with screw cap septum and micro stir bar, substrate $(0.2 \mathrm{mmol}), N, N, N^{\prime}, N^{\prime}$ tetramethylethylenediamine (TMEDA, 3 equiv), photocatalyst (5 $\mathrm{mol} \%$ ), and $3 \mathrm{~mL}$ of solvent were introduced. The mixture was purged with a stream of Ar for $10 \mathrm{~min}$. After deoxygenation, $n-\mathrm{C}_{6} \mathrm{~F}_{13} \mathrm{I}$ ( 3 equiv) was introduced with a microliter syringe followed by a slight stream of Ar being passed through for 1 additional minute; then the vial was sealed. The closed reaction vessel containing a dark red solution is placed on a stir plate above the heat dissipator, according to Figure S1, and stirred vigorously for $20 \mathrm{~h}$. (at $22{ }^{\circ} \mathrm{C}$ ) under constant irradiation with high-power LEDs (3 Watts).

\subsection{Compound characterization}

(3-perfluorohexyl-2-iodopropoxy)benzene (1) obtained as a colorless solid (91\%). TLC: hexane: $\mathrm{CH}_{2} \mathrm{Cl}_{2}(4: 1)$.

${ }^{1}$ H NMR (500 MHz, $\left.\mathbf{C D C l}_{3}\right): \delta(\mathrm{ppm}): 2.81(1 \mathrm{H}, \mathrm{m})$, $3.19(1 \mathrm{H}, \mathrm{m}), 4.19(1 \mathrm{H}, \mathrm{dd} J=10.4 \mathrm{~Hz}, J=6.8 \mathrm{~Hz}), 4.30$ $(1 \mathrm{H}, \mathrm{dd} J=10.4 \mathrm{~Hz}, J=6.8 \mathrm{~Hz}), 4.52(1 \mathrm{H}, \mathrm{m}), 6.92(2 \mathrm{H}, \mathrm{dd}$ $J=8.7 \mathrm{~Hz}, J=1.0 \mathrm{~Hz}), 7.02(1 \mathrm{H}, \mathrm{dt} J=7.4 \mathrm{~Hz}, J=1.0 \mathrm{~Hz})$, $7.31(2 \mathrm{H}, \mathrm{dd}, J=8.7 \mathrm{~Hz}, J=7.4 \mathrm{~Hz}) ;{ }^{13} \mathbf{C}$ NMR $(125 \mathrm{MHz}$, $\left.\mathbf{C D C l}_{3}\right): \delta(\mathrm{ppm}): 12.8,37.8(\mathrm{t}, J=21.1 \mathrm{~Hz}), 72.7,114.9$, 121.9, 129.7, 157.7; ${ }^{19} \mathbf{F}$ NMR (470.585 $\left.\mathbf{~ M H z , ~} \mathbf{C D C l}_{3}\right)$ : $\delta$ (ppm): $-126.01(2 \mathrm{~F}, \mathrm{~m}),-123.56(2 \mathrm{~F}, \mathrm{~m}),-122.83(2 \mathrm{~F}$, $\mathrm{m}),-121.75(2 \mathrm{~F}, \mathrm{~m}),-113.51(2 \mathrm{~F}, \mathrm{~m}),-80.78(3 \mathrm{~F}, \mathrm{t})$;

HRMS (ESI [M+ Na] $]^{+}$): Mass calc. for $\mathrm{C}_{15} \mathrm{H}_{10} \mathrm{~F}_{13} \mathrm{INaO}$ : 602.9466, found for $\mathrm{C}_{15} \mathrm{H}_{10} \mathrm{~F}_{13} \mathrm{INaO}$ : 602.9459.

(2R,3S)-1-perfluorohexyl-2-iodo-3-octanol+enantiomer (2) obtained as a yellow oil (60\%). TLC: isooctane: $\mathrm{CH}_{2} \mathrm{Cl}_{2}$ (4:1).

${ }^{1} \mathrm{H}$ NMR (500 $\left.\mathbf{M H z}, \mathbf{C D C l}_{3}\right): \delta(\mathrm{ppm}): 0.90(3 \mathrm{H}, \mathrm{t}$ $J=6.7 \mathrm{~Hz}), 1.35(6 \mathrm{H}, \mathrm{m}), 1.48(1 \mathrm{H}, \mathrm{m}), 1.58(1 \mathrm{H}, \mathrm{m}), 2.72$ $(1 \mathrm{H}, \mathrm{m}, J=5.2 \mathrm{~Hz}, J=1.7 \mathrm{~Hz}), 2.88(1 \mathrm{H}, \mathrm{m}), 3.11(1 \mathrm{H}, \mathrm{m})$, $4.43(1 \mathrm{H}, \mathrm{m}, J=5.6 \mathrm{~Hz}, J=1.9 \mathrm{~Hz}) ;{ }^{13} \mathbf{C}$ NMR $(125 \mathrm{MHz}$, $\left.\mathbf{C D C l}_{3}\right): \delta(\mathrm{ppm}): 14.0,22.5,25.0,31.1,31.5,38.9(\mathrm{t}$, $J=20.6 \mathrm{~Hz}), 39.3,73.3 ;{ }^{19} \mathbf{F}$ NMR $\left(\mathbf{4 7 0 . 5 8 5} \mathbf{~ M H z}, \mathbf{C D C l}_{3}\right)$ : $\delta(\mathrm{ppm}):-126.11(2 \mathrm{~F}, \mathrm{~m}),-123.51(2 \mathrm{~F}, \mathrm{~m}),-122.84(2 \mathrm{~F}$, m), $-121.75(2 \mathrm{~F}, \mathrm{~m}),-113.11(2 \mathrm{~F}, \mathrm{~m}),-80.77$ (3F, t);

HRMS (ESI [M+ Na] $]^{+}$): Mass calc. for $\mathrm{C}_{14} \mathrm{H}_{16} \mathrm{~F}_{13} \mathrm{INaO}$ : 596.9936, found for $\mathrm{C}_{14} \mathrm{H}_{16} \mathrm{~F}_{13} \mathrm{INaO}$ : 596.9938 .

(2R,3R)-1-perfluorohexyl-2-iodo-3-octanol +enantiomer (3) obtained as a yellow oil (40\%). TLC: isooctane: $\mathrm{CH}_{2} \mathrm{Cl}_{2}(4: 1)$.

${ }^{1} \mathrm{H}$ NMR (500 $\left.\mathbf{M H z}, \mathbf{C D C l}_{3}\right): \delta(\mathrm{ppm}): 0.90(3 \mathrm{H}, \mathrm{t}$ $J=6.7 \mathrm{~Hz}), 1.35(6 \mathrm{H}, \mathrm{m}), 1.48(1 \mathrm{H}, \mathrm{m}), 1.74-1.27(9 \mathrm{H}$, m), $2.77(1 \mathrm{H}, \mathrm{m}), 2.89(1 \mathrm{H}, \mathrm{m}), 3.50(1 \mathrm{H}, \mathrm{m}), 4.42(1 \mathrm{H}$, $\mathrm{m}, J=3.9 \mathrm{~Hz}) ;{ }^{13} \mathbf{C}$ NMR (125 $\left.\mathbf{M H z}, \mathbf{C D C l}_{3}\right): \delta(\mathrm{ppm})$ : $14.0,25.3,27.6,29.7,31.6,34.3,36.5(\mathrm{t}, J=20.7 \mathrm{~Hz})$, 75.7; ${ }^{19}$ F NMR (470.585 MHz, $\left.\mathbf{C D C l}_{3}\right): \delta(\mathrm{ppm}):-126.10$ 
(2F, m) , $-123.58(2 \mathrm{~F}, \mathrm{~m}),-122.82(2 \mathrm{~F}, \mathrm{~m}),-121.75(2 \mathrm{~F}$, $\mathrm{m}),-113.71(2 \mathrm{~F}, \mathrm{~m}),-80.76(3 \mathrm{~F}, \mathrm{t})$;

HRMS (ESI [M + Na] ${ }^{+}$): Mass calc. for $\mathrm{C}_{14} \mathrm{H}_{16} \mathrm{~F}_{13} \mathrm{INaO}$ : 596.9936, found for $\mathrm{C}_{14} \mathrm{H}_{16} \mathrm{~F}_{13} \mathrm{INaO}$ : 596.9935.

(E)-(3-perfluorohexyl-1-iodoprop-1-en-1-yl)benzene (4) obtained as a yellow oil (78\%). TLC: isooctane: $\mathrm{CH}_{2} \mathrm{Cl}_{2}$ (4:1).

${ }^{1}$ H NMR (500 MHz, $\left.\mathbf{C D C l}_{3}\right): \delta(\mathrm{ppm}): 6.62(1 \mathrm{H}, \mathrm{t}$, $J=13.5 \mathrm{~Hz}), 7.30-7.39(5 \mathrm{H}, \mathrm{m}) ;{ }^{13} \mathbf{C}$ NMR $(\mathbf{1 2 5} \mathbf{~ M H z}$, $\left.\mathbf{C D C l}_{3}\right): \delta$ (ppm): $126.8,126.9,127.2,128.0,129.3,130.2$, 141.0; ${ }^{19}$ F NMR (470.585 MHz, $\left.\mathbf{C D C l}_{3}\right)$ : $\delta$ (ppm): -126.17 $(2 \mathrm{~F}, \mathrm{~m}),-122.86(4 \mathrm{~F}, \mathrm{~m}),-121.73(2 \mathrm{~F}, \mathrm{~m}),-105.21(2 \mathrm{~F}$, t), - 80.84 (3F, m); (E)-1-perfluoro-3-iodooct-2-ene (5) obtained as a colorless oil (80\%). TLC: hexane: $\mathrm{CH}_{2} \mathrm{Cl}_{2}$ (4:1).

${ }^{1}$ H NMR (500 MHz, $\left.\mathbf{C D C l}_{3}\right): \delta(\mathrm{ppm}): 0.93(3 \mathrm{H}, \mathrm{t}$, $J=7.2 \mathrm{~Hz}), 1.34(4 \mathrm{H}, \mathrm{m}), 1.61(2 \mathrm{H}, \mathrm{m}), 2.65$ ( $E$-isomer, $2 \mathrm{H}, \mathrm{t}, J=7.5 \mathrm{~Hz}$ ), 2.69 (Z-isomer, $2 \mathrm{H}, \mathrm{t}, J=6.9 \mathrm{~Hz}), 6.26$ $(Z$-isomer, $1 \mathrm{H}, \mathrm{t}, J=13.2 \mathrm{~Hz}), 6.34(E$-isomer, $1 \mathrm{H}, 2 \mathrm{H}$, t, $J=14.5 \mathrm{~Hz}) ;{ }^{13} \mathbf{C}$ NMR (125 MHz, $\left.\mathbf{C D C l}_{3}\right): \delta(\mathrm{ppm})$ : $13.9,14.1,22.3,22.7,29.4,29.7,30.2,30.6,31.4,31.9$, 41.1, 48.4, $123.1(\mathrm{t}, J=6.8 \mathrm{~Hz}), 126.4(\mathrm{t}, J=23.8) ;{ }^{19} \mathbf{F}$ NMR (470.585 MHz, $\left.\mathbf{C D C l}_{3}\right): \delta(\mathrm{ppm}):-126.11(2 \mathrm{~F}$, $\mathrm{m}),-123.26(2 \mathrm{~F}, \mathrm{~m}),-122.82(2 \mathrm{~F}, \mathrm{~m}),-121.66(2 \mathrm{~F}$, $\mathrm{m}),-108.44$ ( $Z$-isomer, $2 \mathrm{~F}, \mathrm{t}),-105.37$ ( $E$-isomer, $2 \mathrm{~F}$, t), $-80.77(3 \mathrm{~F}, \mathrm{t})$;

(D)-(-)Norgestrel- $\mathbf{C}_{6} \mathbf{F}_{13}$ (7): obtained as a colorless oil, (50\%). ${ }^{1} \mathbf{H}$ NMR (500 $\left.\mathbf{M H z}, \mathbf{C D C l}_{3}\right): \delta(\mathrm{ppm}): 0.75(\mathrm{~m}$, $1 \mathrm{H}), 0.97(\mathrm{~m}, 1 \mathrm{H}), 1.08(\mathrm{~m}, 1 \mathrm{H}), 1.10(\mathrm{t}, 3 \mathrm{H}, J=7.3 \mathrm{~Hz})$, $1.18(\mathrm{~m}, 1 \mathrm{H}), 1.45(\mathrm{~m}, 1 \mathrm{H}), 1.54(\mathrm{~m}, 3 \mathrm{H}), 1.65(\mathrm{~m}, 2 \mathrm{H})$, $1.73(\mathrm{~m}, 1 \mathrm{H}), 1.87(\mathrm{~m}, 2 \mathrm{H}), 1.98(\mathrm{~m}, 1 \mathrm{H}), 2.08-2.17(\mathrm{~m}$, $2 \mathrm{H}), 2.29(\mathrm{~m}, 3 \mathrm{H}), 2.43(\mathrm{~m}, 1 \mathrm{H}), 2.52(\mathrm{~m}, 1 \mathrm{H}), 2.57(\mathrm{~m}$, $1 \mathrm{H}), 5.52(\mathrm{~m}, 1 \mathrm{H}), 5.85(\mathrm{~s}, 1 \mathrm{H}), 6.41(\mathrm{~d}, 1 \mathrm{H}, J=10 \mathrm{~Hz}$, H-F); ${ }^{13} \mathbf{C}$ NMR (125 MHz, $\mathbf{C D C l}_{\mathbf{3}}$ ): $\delta$ (ppm): 9.6, 21.2, 21.6, 23.4, 26.1, 26.8, 28.3, 30.8, 34.1, 35.5, 36.6, 40.7, $42.4,48.4,49.0,116.3(\mathrm{t}, J=23.55 \mathrm{~Hz}), 125.01,144.72(\mathrm{t}$, $J=8.7 \mathrm{~Hz}), 165.9,169.6,199.8 ;{ }^{19}$ F NMR $(\mathbf{4 7 0 . 5 8 5} \mathbf{~ M H z}$, $\mathbf{C D C l}_{3}$ ): $\delta(\mathrm{ppm}):-80.76(\mathrm{t}, 3 \mathrm{~F}, J=9 \mathrm{~Hz}),-111.13$ (cplx m, 2F), -121.51 (br s, 2F), - 122.84 (br s, 2F), - 123.11 (br s, 2F), 126.08 (br s, 2F);

HRMS (ESI [M+Na] $]^{+}$): Mass calc. for $\mathrm{C}_{29} \mathrm{H}_{31} \mathrm{~F}_{13} \mathrm{NaO}_{3}$ : 697.1970, found for $\mathrm{C}_{29} \mathrm{H}_{31} \mathrm{~F}_{13} \mathrm{NaO}_{3}$ : 697.1958.

2,6-dimethyl-4-(perfluorohexyl)aniline ${ }^{17}(8)$ obtained as a white solid (95\%). TLC: isooctane: $\mathrm{CH}_{2} \mathrm{Cl}_{2}(1: 1)$.

${ }^{1} \mathrm{H}$ NMR (600 MHz, $\left.\mathbf{C D C l}_{3}\right): \delta(\mathrm{ppm}): 2.21(6 \mathrm{H}, \mathrm{s})$, 3.88 (2H, br s), $7.14(2 \mathrm{H}, \mathrm{s}) ;{ }^{13} \mathbf{C}$ NMR $(\mathbf{1 5 0 . 9 0 3} \mathbf{~ M H z}$, $\left.\mathbf{C D C l}_{3}\right): \delta(\mathrm{ppm}): 17.7,117.4(\mathrm{~m}), 121.2,126.9,146.2 ;{ }^{19} \mathbf{F}$ NMR (564.603 MHz, $\mathbf{C D C l}_{3}$ ): $\delta(\mathrm{ppm}):-126.17(2 \mathrm{~F}, \mathrm{br}$ s), $-122.86(2 \mathrm{~F}$, br s), -121.77 (2F, br s), -121.53 (2F, br s), $-109.18(2 \mathrm{~F}, \mathrm{t}),-80.84(3 \mathrm{~F}, \mathrm{t})$.

4-methyl-2-(perfluorohexyl)aniline $e^{17}$ (9) obtained as a yellow oil (80\%). TLC: isooctane: $\mathrm{CH}_{2} \mathrm{Cl}_{2}(1: 1)$.
${ }^{1}$ H NMR (600 MHz, CDCl 3 ): $\delta$ (ppm): 2.26 (3H, s), 4.08 $(2 \mathrm{H}$, br s), $6.63(1 \mathrm{H}, \mathrm{d}, J=9.2 \mathrm{~Hz}), 7.10(2 \mathrm{H}$, overlapped d $\& \mathrm{~s}) ;{ }^{13} \mathbf{C}$ NMR (150.903 $\left.\mathbf{~ M H z}, \mathbf{C D C l}_{3}\right): \delta$ (ppm): 20.4, $111.3(\mathrm{t}), 118.2,127.3,128.9$ (t), 134.0, 143.6; ${ }^{19} \mathbf{F}$ NMR (564.603 MHz, $\left.\mathbf{C D C l}_{3}\right)$ : $\delta(\mathrm{ppm}):-126.11(2 \mathrm{~F}, \mathrm{~m}),-122.7$ $(2 \mathrm{~F}, \mathrm{~m}),-121.8(4 \mathrm{~F}, \mathrm{~m}),-108.40(2 \mathrm{~F}, \mathrm{t}),-80.75(3 \mathrm{~F}, \mathrm{t})$.

4-methoxy-2-(perfluorohexyl)aniline ${ }^{17}$ (10) obtained as a yellow solid (47\%). TLC: $\mathrm{CH}_{2} \mathrm{Cl}_{2}:$ Hexane (7:3).

${ }^{1} \mathrm{H}$ NMR (500 $\left.\mathbf{~ M H z}, \mathbf{C D C l}_{3}\right): 3.76(5 \mathrm{H}$, overlapped br s and singlet), $6.70(1 \mathrm{H}, \mathrm{d}, J=8.7 \mathrm{~Hz}), 6.84(1 \mathrm{H}, \mathrm{d}$, $J=2.8 \mathrm{~Hz}), 6.94(1 \mathrm{H}, \mathrm{dd}, J=8.8 \mathrm{~Hz}, J=2.8 \mathrm{~Hz}) ;{ }^{13} \mathrm{C}$ NMR (125 MHz, $\left.\mathbf{C D C l}_{3}\right): 56.0,112.1(\mathrm{t}, J=22.5 \mathrm{~Hz})$, $113.1(\mathrm{t}, J=8.9 \mathrm{~Hz}), 119.8,120.5,139.7,152.1 ;{ }^{19} \mathbf{F}$ NMR (470.585 MHz, $\left.\mathbf{C D C l}_{3}\right)$ : - 126.15 (2F, m), - 122.76 (2F, m), $-121.75(4 \mathrm{~F}, \mathrm{~m}),-108.64(2 \mathrm{~F}, \mathrm{~m}),-80.83(3 \mathrm{~F}, \mathrm{~m})$.

4-methoxy-3-(perfluorohexyl)aniline ${ }^{17}$ (11) obtained as a yellow solid (3\%). TLC: $\mathrm{CH}_{2} \mathrm{Cl}_{2}$ :Hexane (7:3).

${ }^{1} \mathrm{H}$ NMR (500 $\left.\mathbf{M H z}, \mathbf{C D C l}_{3}\right): 3.79$ (5H, overlapped br s and singlet), 6.85 (3H, overlapped d \& s); ${ }^{13} \mathbf{C}$ NMR (125 MHz, $\left.\mathbf{C D C l}_{\mathbf{3}}\right)$ : 57.0, 114.8, $115.8(\mathrm{t}, J=8.8 \mathrm{~Hz}), 117.9$ $(\mathrm{t}, J=22.6 \mathrm{~Hz}), 120.2,139.9,151.7(\mathrm{t}, J=2.7 \mathrm{~Hz}) ;{ }^{19} \mathbf{F}$ NMR (470.585 MHz, CDCl $\left.{ }_{3}\right)$ : 126.14 (2F, m), - 122.72 (2F, m) $-121.91(2 \mathrm{~F}, \mathrm{~m}),-121.19$ (2F, m) -107.75 (2F, $\mathrm{m}),-80.80(3 \mathrm{~F}, \mathrm{t})$.

4-nitro-2-(perfluorohexyl)aniline $e^{17}$ (12) obtained as a yellow solid (30\%). TLC: $\mathrm{CH}_{2} \mathrm{Cl}_{2}:$ Hexane (7:3).

${ }^{1} \mathrm{H}$ NMR (500 MHz, $\mathbf{C D C l}_{3}$ ): 4.98 (2H, br s), 6.75 $(1 \mathrm{H}, \mathrm{d}, J=9.1 \mathrm{~Hz}), 8.17(1 \mathrm{H}, \mathrm{dd}, J=9.1 \mathrm{~Hz}, J=2.5 \mathrm{~Hz})$, $8.30(1 \mathrm{H}, \mathrm{d}, J=2.5 \mathrm{~Hz}) ;{ }^{13} \mathbf{C}$ NMR $\left(\mathbf{1 2 5} \mathbf{~ M H z}, \mathbf{C D C l}_{3}\right)$ : $110.1(\mathrm{t}, J=23.8 \mathrm{~Hz}), 117.3,126.8(\mathrm{t}, J=9.1 \mathrm{~Hz}), 128.8$, 138.7, $151.0 ;{ }^{\mathbf{1 9}} \mathbf{F}$ NMR (470.585 $\left.\mathbf{~ M H z}, \mathbf{C D C l}_{\mathbf{3}}\right)$ : -126.11 $(2 \mathrm{~F}, \mathrm{~m}),-122.70(2 \mathrm{~F}, \mathrm{~m}),-121.74(2 \mathrm{~F}, \mathrm{~m}),-121.62(2 \mathrm{~F}$, $\mathrm{m}),-109.31(2 \mathrm{~F}, \mathrm{~m}),-80.78(3 \mathrm{~F}, \mathrm{t})$.

4-(tert-butyl)-1-methoxy-2-(perfluorohexyl)benzene ${ }^{17}$ (13) obtained as a colorless liquid (50\%). TLC: Hexane: AcOEt (9:1).

${ }^{1}$ H NMR (500 MHz, $\left.\mathbf{C D C l}_{3}\right): 1.31$ (9H, s), $3.84(3 \mathrm{H}, \mathrm{s})$, $6.95(1 \mathrm{H}, \mathrm{d}, J=8.7 \mathrm{~Hz}), 7.48(1 \mathrm{H}, \mathrm{d}, J=2.5 \mathrm{~Hz}), 7.52(1 \mathrm{H}$, $\mathrm{dd}, J=8.7 \mathrm{~Hz}, J=2.5 \mathrm{~Hz}) ;{ }^{13} \mathbf{C}$ NMR $\left(\mathbf{1 2 5} \mathbf{M H z}, \mathbf{C D C l}_{3}\right)$ : 31.5, 34.4, 56.2, 112.4, 116.4, 126.2 (t, $J=8.4 \mathrm{~Hz}), 130.4$, 143.3, 156.4; ${ }^{19}$ F NMR (470.585 $\left.\mathbf{~ M H z , ~} \mathbf{C D C l}_{3}\right)$ : - 126.15 (2F, m) $-122.73(2 \mathrm{~F}, \mathrm{~m}),-121.90(2 \mathrm{~F}, \mathrm{~m}),-121.29$ (2F, $\mathrm{m}),-107.59(2 \mathrm{~F}, \mathrm{~m}),-80.82(3 \mathrm{~F}, \mathrm{t})$.

1,2-dimethoxy-4-(perfluorohexyl)benzene $e^{17}$ (14) obtained as a yellow oil (55\%). TLC: $\mathrm{CH}_{2} \mathrm{Cl}_{2}:$ isooctane (7:3).

${ }^{1} \mathrm{H}$ NMR (600 MHz, $\left.\mathbf{C D C l}_{3}\right): \delta(\mathrm{ppm}): 3.92(3 \mathrm{H}$, s), $3.94(3 \mathrm{H}, \mathrm{s}), 6.95(1 \mathrm{H}, \mathrm{d}, J=8.5 \mathrm{~Hz}), 7.02(1 \mathrm{H}, \mathrm{d}$, $J=1.6 \mathrm{~Hz}), 7.18(1 \mathrm{H}, \mathrm{dd}, J=8.5 \mathrm{~Hz}, J=1.6 \mathrm{~Hz}) ;{ }^{13} \mathbf{C} \mathbf{~ N M R}$ (150.903 MHz, $\left.\mathbf{C D C l}_{3}\right): \delta$ (ppm): 56.1, 56.2, 109.6, 110.8, 120.4, 121.1, 149.1, 150.0; ${ }^{19}$ F NMR (564.603 MHz, $\left.\mathbf{C D C l}_{3}\right): \delta(\mathrm{ppm}):-126.14(2 \mathrm{~F}, \mathrm{br} \mathrm{s}),-122.83(2 \mathrm{~F}, \mathrm{br}$ 
s), $-121.86(2 \mathrm{~F}, \mathrm{~m}),-121.41(2 \mathrm{~F}, \mathrm{~m}),-109.64(2 \mathrm{~F}$, t), $-80.78(3 \mathrm{~F}, \mathrm{t})$.

1,3,5-trimethoxy-2-(perfluorohexyl)benzene $e^{17}$ (15) obtained as a white solid (90\%). TLC: Hexane: $\mathrm{CH}_{2} \mathrm{Cl}_{2}$ (3:1).

${ }^{1} \mathrm{H}$ NMR (400 MHz, $\left.\mathbf{C D C l}_{3}\right): 3.8(6 \mathrm{H}, \mathrm{s}), 3.84(3 \mathrm{H}$, s), $6.15(2 \mathrm{H}, \mathrm{s}) ;{ }^{13} \mathbf{C}$ NMR (100 $\left.\mathbf{~ M H z}, \mathbf{C D C l}_{3}\right): 55.5$, $56.5,91.9,98.64,161.92(\mathrm{t}, J=2.2 \mathrm{~Hz}), 164.0 ;{ }^{19} \mathbf{F}$ NMR (470.585 MHz, $\left.\mathbf{C D C l}_{3}\right)$ : $-126.18(2 \mathrm{~F}, \mathrm{~m}),-122.70$ $(2 \mathrm{~F}, \mathrm{~m}),-122.26(2 \mathrm{~F}, \mathrm{~m}),-122.1(2 \mathrm{~F}, \mathrm{~m}),-102.7$ (2F, $\mathrm{m}),-80.87(3 \mathrm{~F}, \mathrm{t})$.

Ulipristal- $\mathbf{C}_{6} \mathbf{F}_{13}$ (17): obtained as a yellow oil (65\%). ${ }^{1} \mathbf{H}$ NMR (500 MHz, $\mathbf{C D C l}_{3}$ ): $\delta(\mathrm{ppm}): 0.40(3 \mathrm{H}, \mathrm{s}) ; 1.39$ $(1 \mathrm{H}, \mathrm{m}) ; 1.53(1 \mathrm{H}, \mathrm{m}) ; 1.77(1 \mathrm{H}, \mathrm{m}) ; 1.83(1 \mathrm{H}, \mathrm{m}) ; 2.03$ $(1 \mathrm{H}, \mathrm{m}) ; 2.09(1 \mathrm{H}, \mathrm{m}) ; 2.12(3 \mathrm{H}, \mathrm{s}) ; 2.15(3 \mathrm{H}, \mathrm{s}) ; 2.29(1 \mathrm{H}$, $\mathrm{d}, J=12 \mathrm{~Hz}) ; 2,36(1 \mathrm{H}, \mathrm{m}) ; 2.51(2 \mathrm{H}, \mathrm{m}$, superimposed signals); $2.62(3 \mathrm{H}, \mathrm{m}$, superimposed signals $) ; 2.79(1 \mathrm{H}$, m); $2.91(1 \mathrm{H}, \mathrm{m}) ; 2.94(6 \mathrm{H}, \mathrm{s}) ; 3.08(1 \mathrm{H}, \mathrm{m}) ; 4.42(1 \mathrm{H}, \mathrm{d}$, $J=8 \mathrm{~Hz}) ; 6.67(2 \mathrm{H}, \mathrm{d}, J=7.7 \mathrm{~Hz}) ; 6.99(2 \mathrm{H}, \mathrm{d}, J=7.8 \mathrm{~Hz})$; ${ }^{13} \mathbf{C}$ NMR (125 MHz, $\left.\mathbf{C D C l}_{3}\right): \delta$ (ppm): 15.9; 21.4; 24.1; $25.6 ; 27.0 ; 27.3 ; 29.8 ; 30.6 ; 37.0 ; 37.8 ; 38.1 ; 40.1 ; 40.6$; $47.1 ; 50.9 ; 96.0 ; 112.9 ; 127.3 ; 130.6 ; 130.8 ; 149.0 ; 151.4$; 162.5; 170.7; 193.3; 203.8; ${ }^{19}$ F NMR (470.585 MHz, $\left.\mathbf{C D C l}_{3}\right): \delta(\mathrm{ppm}):-80.73(3 \mathrm{~F}, \mathrm{t}),-101.28(2 \mathrm{~F}, \mathrm{~m}),-119.60$ $(2 \mathrm{~F}, \mathrm{~m}),-121.87$ (2F, br s), -122.59 (2F, br s), 126.05 (2F, br s);

HRMS (ESI [M+ $\mathbf{H}]^{+}$): Mass calc. for $\mathrm{C}_{36} \mathrm{H}_{37} \mathrm{~F}_{13} \mathrm{NO}_{4}$ : 794.2515, found for $\mathrm{C}_{36} \mathrm{H}_{37} \mathrm{~F}_{13} \mathrm{NO}_{4}$ : 794.2522.

Supplementary Information The online version contains supplementary material available at https://doi.org/10.1007/s43630-021-00154-3.

Acknowledgements DEY thanks a post-doctoral scholarship to Consejo Nacional de Investigaciones Científicas y Técnicas, Conicet. SBV and AP are research members of Conicet. The following financial agencies are acknowledged: Consejo Nacional de Investigación Científica y Técnica (Conicet) (Grant Number: $11220200100115 C O$ ), Secretaría de Ciencia y Técnica de la Universidad de Buenos Aires (UBA-SeCyT) (Grant Number: 20020190100020BA), and Agencia Nacional de Promoción Científica y Técnica (ANPCyT) (Grant Number: PICT-2017-2276).

Funding Secretaría de Ciencia y Técnica, Universidad de Buenos Aires, 20020190100020BA, Al Postigo, Consejo Nacional de Investigaciones Científicas y Técnicas, 11220200100115CO, Al Postigo, ANPCYT, PICT-2017-276, Al Postigo.

\section{Declarations}

Conflict of interest The authors herein declare no conflict of interests.

\section{References}

1. Barata-Vallejo, S., Yerien, D. E., \& Postigo., A. (2021). Advances in photocatalytic organic synthetic transformations in water and aqueous media. ACS Sustainable Chemistry and Engineering, 9, 10016-10047. https://doi.org/10.1021/acssuschemeng.1c03384

2. Cheung, K. P. S., Sarkar, S., \& Gevorgyan, V. (2021). Visible light-induced transition metal catalysis. Chemical Reviews. https:// doi.org/10.1021/acs.chemrev.1c00403

3. Dichiarante, V., \& Bergamaschi, G. (2019). Photochemistry of transition metal complexes (2017-2018). Photochemistry. https://doi.org/10.1039/9781788016520-00241.ISBN: 978-1-78801-554-7

4. Dichiarante, V., Strada, A., \& Bergamaschi, G. (2021). Photochemistry of transition metal complexes (2019-2020). Photochemistry. https://doi.org/10.1039/9781839165269-00177.ISBN: 978-1-78801-554-7

5. Cannalire, R., Pelliccia, S., Sancineto, L., Novellino, E., Tron, G. C., \& Giustiniano, M. (2020). Visible light photocatalysis in the late-stage functionalization of pharmaceutically relevant compounds. Chemical Society Reviews, 50, 766-897. https://doi.org/ 10.1039/D0CS00493F

6. Bloom, S., McCann, M., \& Lectka, T. (2014). Photocatalyzed benzylic fluorination: shedding "light" on the involvement of electron transfer. Organic Letters, 16(24), 6338-6341. https://doi.org/10. 1021/ol503094m

7. Rueda-Marquez, J. J., Levchuk, I., Fernández Ibañez, P., \& Sillanpää, M. A. (2020). Critical review on application of photocatalysis for toxicity reduction of real wastewaters. Journal of Cleaner Production, 258, 120694. https://doi.org/10.1016/j.jclepro.2020. 120694

8. Sun, K., Lv, Q.-Y., Chen, X.-L., Qu, L.-B., \& Yu, B. (2021). Recent Advances in visible-light-mediated organic transformations in water. Green Chemistry, 23(1), 232-248. https://doi.org/ 10.1039/D0GC03447A

9. Barata-Vallejo, S., \& Postigo, A. (2020). New visible light-triggered photocatalytic trifluoromethylation reactions of carbon-carbon multiple bonds and (hetero)aromatic compounds. Chemistry $A$ European Journal, 26, 5303-5551. https://doi.org/10.1002/chem. 202000856

10. Mora Flores, E., Uhrig, M. L., \& Postigo, A. (2020). Photocatalyzed reductive fluoroalkylation of 2-acetoxyglycals towards the stereoselective synthesis of a-1-fluoroalkyl-C-glycosides. Organic and Biomolecular Chemistry, 18, 8724-8734. https://doi.org/10. 1039/D0OB01914C

11. Yerien, D. E., Barata-Vallejo, S. M., Flores, E., \& Postigo, A. (2020). The role of photocatalysts in radical chains of homolytic aromatic substitutions, radical addition to olefins, and nucleophilic radical substitution mechanisms. Catalysis Science and Technology, 10, 5113-5128. https://doi.org/10.1039/D0CY00921K

12. Yerien, D. E., Cooke, M. V., García Vior, M. C., Barata-Vallejo, S., \& Postigo, A. (2019). Radical fluoroalkylation reactions of (hetero)arenes and sulfides under red light photocatalysis. Organic and Biomolecular Chemistry, 17, 3741-3747. https://doi.org/10. 1039/C9OB00486F

13. Lantaño, B., Barata-Vallejo, S., \& Postigo, A. (2018). Organic Dye-Photocatalyzed Perfluoroalkylation of Heteroarene-N-oxide Derivatives. Organic and Biomolecular Chemistry, 16, 67186727. https://doi.org/10.1039/C8OB01653D

14. Barata-Vallejo, S., Yerien, D., \& Postigo, A. (2015). Benign perfluoroalkylation of aniline derivatives through photoredox organocatalysis under visible light irradiation. European Journal of Organic Chemistry, 2015, 7869-7875. https://doi.org/10.1002/ ejoc.201501189

15. Mecinović, J., Snyder, P. W., Mirica, K. A., Bai, S., Mack, E. T., Kwant, R. L., Moustakas, D. T., Héroux, A., \& Whitesides, G. M. (2011). Fluoroalkyl and alkyl chains have similar hydrophobicities in binding to the "hydrophobic wall" of carbonic anhydrase. Journal of the American Chemical Society, 133(35), 14017-14026. https://doi.org/10.1021/ja2045293 
16. Nguyen, T.-T.H., O’Brien, C. J., Tran, M. L. N., Olson, S. H., Settineri, N. S., Prusiner, S. B., Paras, N. A., \& Conrad, J. (2021). Water-soluble iridium photoredox catalyst for the trifluoromethylation of biomolecule substrates in phosphate buffered saline solvent. Organic Letters, 23(10), 3823-3827. https://doi.org/10. 1021/acs.orglett.1c00871

17. Yerien, D. E., Postigo, A., Baroncini, M., \& Barata-Vallejo, S. (2021). Bioinspired photocatalysed C-H fluoroalkylation of arenes in water promoted by native vitamin B12 and Rose Bengal. Green Chemistry. https://doi.org/10.1039/D1GC02654B

18. Barata-Vallejo, S., \& Postigo, A. (2019). Photocatalytic difluoromethylation reactions of aromatic compounds and aliphatic carbon-carbon multiple bonds. Molecules, 24, 4483. https://doi. org/10.3390/molecules24244483

19. Liu, X., Qing, Z., Cheng, P., Zheng, X., Zeng, J., \& Xie, H. (2016). Metal-free photoredox catalyzed cyclization of O-(2,4dinitrophenyl)oximes to phenanthridines. Molecules, 21(12), 1690. https://doi.org/10.3390/molecules21121690

20. Wallentin, C. J., Nguyen, J. D., Finkbeiner, P., \& Stephenson, C. R. J. (2012). Visible light-mediated atom transfer radical addition via oxidative and reductive quenching of photocatalysts. Journal of the American Chemical Society, 134(21), 8875-8884. https:// doi.org/10.1021/ja300798k

21. Yasu, Y., Koike, T., \& Akita, M. (2012). Three-component oxytrifluoromethylation of alkenes: highly efficient and regioselective difunctionalization of $\mathrm{C}=\mathrm{C}$ bonds mediated by photoredox catalysts. Angewandte Chemie International Edition, 51, 9567-9571. https://doi.org/10.1002/anie.201205071

22. Zhang, Z., Tang, X. J., \& Dolbier, W. R., Jr. (2015). Photoredoxcatalyzed tandem insertion/cyclization reactions of difluoromethyl and 1,1-difluoroalkyl radicals with biphenyl isocyanides. Organic Letters, 17, 4401-4403. https://doi.org/10.1021/acs.orglett.5b020 61

23. Li, L., Huang, M., Liu, C., Xiao, J.-C., Chen, Q.-Y., Guo, Y., \& Zhao, Z.-G. (2015). 2,2,2-Trifluoroethylation of styrenes with concomitant introduction of a hydroxyl group from molecular oxygen by photoredox catalysis activated by visible light. Organic Letters, 17, 4714-4717. https://doi.org/10.1021/acs.orglett.5b02177

24. Xiao, Y., Chun, Y.-K., Cheng, S.-C., Liu, R., Tse, M.-K., \& Ko, C.-C. (2020). Visible light photocatalytic cross-coupling and addition reactions of arylalkynes with perfluoroalkyl iodides. Organic \&amp; Biomolecular Chemistry, 18, 8686-8693. https://doi.org/ 10.1039/D0OB01767A

25. Corsico, S., Fagnoni, M., \& Ravelli, D. (2017). Sunlight decatungstate photoinduced trifluoromethylations of (hetero)aromatics and electron-poor olefins. Photochemical \&amp; Photobiological Sciences, 16, 1375-1380. https://doi.org/10.1039/C7PP00179G

26. Ding, B., Weng, Y., Liu, Y., Song, C., Yin, L., Yuan, J., Ren, Y., Lei, A., \& Chiang, C.-W. (2019). Selective photoredox trifluoromethylation of tryptophan-containing peptides. European Journal of Organic Chemistry. https://doi.org/10.1002/ejoc.201901572

27. Wang, X., Lei, J., Liu, Y., Ye, Y., Li, J., \& Sun, K. (2021). Fluorination and fluoroalkylation of alkenes/alkynes to construct fluoro-containing heterocycles. Organic Chemistry Frontiers, 8, 2079-2109. https://doi.org/10.1039/D0QO01629B

28. Nguyen, J. D., Tucker, J. W., Konieczynska, M. D., \& Stephenson, C. R. J. (2011). Intermolecular atom transfer radical addition to olefins mediated by oxidative quenching of photoredox catalysts. Journal of the American Chemical Society, 133(12), 4160-4163. https://doi.org/10.1021/ja108560e

29. Yajima, T., \& Ikegami, M. (2017). Metal-free visible-light radical iodoperfluoroalkylation of terminal alkenes and alkynes. European Journal of Organic Chemistry, 2017(15), 2126-2129. https://doi.org/10.1002/ejoc.201700077

30. Slodowicz, M., Barata Vallejo, S., Vazquez, A., Nudelman, N., \& Postigo, A. (2012). Light-induced iodoperfluoroalkylation reactions of carbon-carbon multiple bonds in water. Journal of Fluorine Chemistry, 135, 137-143. https://doi.org/10.1016/j.jfluchem. 2011.10.002

31. Davis, C. R., Burton, D. J., \& Yang, Z.-Y. (1995). Titanium-catalyzed addition of perfluoroalkyl iodides to alkenes. Journal of Fluorine Chemistry, 70, 135-140. https://doi.org/10.1016/00221139(94)03102-6

32. Dgren, R. A., \& Stanczyk, F. Z. (1999). Nomenclature of the gonane progestins. Contraception, 60(6), 313. https://doi.org/10. 1016/s0010-7824(99)00101-8

33. World Health Organization. (2019). World Health Organization model list of essential medicines: 21 st list 2019. World Health Organization.

34. Garnock-Jones, K. P., \& Duggan, S. T. (2017). Ulipristal acetate: a review in symptomatic uterine fibroids. Drugs, 77(15), 16651675. https://doi.org/10.1007/s40265-017-0812-3.PMID289008 97

35. Reischauer, S., \& Pieber, B. (2021). Emerging concepts in photocatalytic organic synthesis. iScience. https://doi.org/10.1016/J. ISCI.2021.102209

36. Tahara, K., \& Hisaeda, Y. (2011). Eco-friendly molecular transformations catalyzed by a vitamin B12 derivative with a visiblelight-driven system. Green Chemistry, 13, 558-561. https://doi. org/10.1039/b000000x 